\title{
The Islamic Monetary Standard: The Dinar and Dirham
}

\section{Adam Abdullah *}

\author{
Received: 14.12 .2019
}

Accepted: 28.03.2020

DOI: $10.25272 /$ ijisef.659330

Type: Research Article

\begin{abstract}
The Shari'ah not only considers the Islamic monetary standard as a medium of exchange, unit of account, store of value and a standard of deferred payment, but the Islamic functions of money also determine Shari'ah legal injunctions concerning zakat (poor tax), jizya (poll tax), kharaj (tax on conquered territory), diyyat (blood-money), sariqa (theft), mahar (dowry) and sarf (exchange). This study seeks to clarify the weight of the dinar and dirham, since they impart justice as part of Shari'ah law. Through library research and content analysis of literature from the hadith, scholars, mint-masters and writers, different regions had different weights and coin standards, which might imply differing opinions as to what constitutes a legal dinar and dirham. However, narrations have clarified the relationships between the Byzantine dinar and the mithqal of Persia, Makkah, Syria, Egypt and Iraq. Combined with additional numismatic and metrological analysis of surviving coins and glass weights, we discover that each mithqal, dirham, daniq, qirat, habbah and khardal are defined differently, but reflect the same standard of the Prophet (s.a.w.s.) that was later externalized with the minting of the first Islamic dinars and dirhams by Caliph cAbd al-Malik ibn Marwan, involving modern equivalents weights of $4.25 \mathrm{~g}$ and $2.975 \mathrm{~g}$.
\end{abstract}

Keywords: Islamic Currency, Islamic Economics, Monetary Economics

Jel Codes: E42, E52, N15

\footnotetext{
Al Qasimia University, United Arab Emirates, aabdullah@alqasimia.ac.ae, ORCID: https://orcid.org/0000-0001-6733-5647
} 


\section{Introduction}

Money is the common denominator for all economic transactions. Man is free to choose any other medium of exchange, but there are implications for doing so. Ibn Khaldun (the father of Islamic economics) tried to warn the Mamluk government in his Muqaddimah (written in 1377), from avoiding monetary mis-management, as it would lead to their collapse. Ibn Khaldun died in 1404, the year that Egypt suffered a hyper-inflationary depression that resulted in the destruction of half of the human population and all of the livestock in 1405 as a result of famine and plague, the latter which Al-Maqrizi, the student of Ibn Khaldun, attributed to punishment from Allah (s.w.t.). Al-Maqrizi wrote the Ighathah in 1405 (Al-Maqrizi, 1994, 1940) and al-Nuqud al-Islamiyyah ('The Islamic Currency') in 1415 (Al-Maqrizi, 1967) as emphatic warnings to Muslims not to discard the dinar and dirham for any other medium of exchange including a fiat currency such as copper (fulus). "[The people] should deal exclusively with gold and silver for pricing goods" (Al-Maqrizi, 1994, p.80), and "Allah (s.w.t.) never made [fulus] legal tender" (An-Nuqud, 1967, p.34 cited by Meloy, 2003, p.200). Furthermore, one of the functions of money in Islam specifically mentions the dinar and dirham in imparting justice, involving Shari'ah legal injunctions regarding zakat (poor tax), jizya (poll tax), kharaj (tax on conquered territory), diyyat (blood-money), sariqa (theft), mahar (dowry) and sarf (exchange).

Therefore, this study provides a comprehensive analysis of the dinar and dirham. This also requires a satisfactory explanation of the Islamic currency in relation to other regional coin weights and standards. It should be mentioned that the unit or measure of value was a function of money that also reflected an "accounting unit of value" or "money of account". Such a unit of value lacked the external physical form of coinage, it was still 'real', given that it was linked to weight standards of circulating gold and silver coins. Indeed, at the time of the Prophet (s.a.w.s.), the theoretical weights of the dinar and dirham for the payment of zakat were monies of account. Although, circulating Sassanian and Byzantine coins were adopted, the external weight and fineness of the Islamic dinar and dirham were only later minted by the Umayyad caliph cAbd al-Malik ibn Marwan (r.a.) in the year 697 (77H). Subsequently, two important "monies of account" would also later evolve in Egypt: the army dinar (dinar jayshi), which was used to value land $\left(i q t a^{c}\right)$ distributed by the Sultan, and also the copper dirham of account (dirham min'l fulus), which was used to convert the value of existing coinage and introduced at the time of the collapse of the Mamluk gold and silver monetary system.

In reality, coins circulated by specie (intrinsic value) and not by tale (face value). The dinar and the dirham were different currencies and would be assessed according to their respective bullion content and purity, the supply and demand gold and silver coinage, and whether a coin was accepted for the payment of Islamic taxes and by preference (Muslims would prefer Islamic inscriptions rather than other images, motifs or inscriptions). Under a bimetallic commodity standard, bad money would drive out good money when a coin of low intrinsic value ('bad money') circulated with a coin at par, of equal extrinsic value but higher intrinsic value ('good money'). The lighter coin of lower value would be spent rather than the heavier coin of higher value, which would then be sold abroad. However, Gresham's Law would not 
apply if differing coinage circulated at market exchange rates according to their intrinsic value alone. Indeed, the Geniza documents (Goitein, 2000, 1, pp.229-266) confirmed that coins fluctuated with differing exchange rates according to the supply and demand of metal and the precious metal content - notwithstanding the cost of production and minting (brassage), which was absorbed by the mint (sikka) (Udovitch et al, 1978, p.124; Goitein, 1965, p.44). The price of goods and services, or "God's price" (si'r Allah), agreed on in the market, was not distorted or inconvenienced given the intrinsic rates of exchange, and not only provided an equivalent counter-value, but were fully considered in business transactions. The role of the moneychanger (sarafi), therefore, was to determine the relative fair rates of exchange between two coins according to instrinsic value. It would be incorrect to generalize that coins in circulation where fixed in relation to each other, so that the Fatimids had adopted a bimetallic commodity standard, the Ayyubids a gold commodity standard, and that the Mamluks had initially adopted a gold commodity standard supported by silver, followed by a silver commodity standard supported by copper. The evidence does not reveal that these dynasties formally adopted any of these standards (Schultz, 2008, 1, pp.321-323). However, government proclamations, edicts, and debasement of currencies and monies of account, certainly did occur, which in terms of monetary policy, served to undermine the value and purchasing power of money. Generally, silver (fiddah) and gold (dhahab) were essentially unitized into dirhams and dinars, so that for legal and official purposes, lower quality dirhams were referenced to in texts and differentiated from higher quality dirhams (dirham nuqrah) that were in circulation at the time (Rabie 1972, p.162ff; Schultz 1995, pp.147-9,163,234-5; Borsch 2005, pp.68-71; Goitein 1965, p.35).

\section{Islamic Monetary Standard}

The Islamic monetary standard is essentially a theory of coinage: "the dinar and dirham have not been created...but as the medium of exchange for things" (Ihya, 2004, 4, pp.90-91; Usmani, 2001, pp.81-83). The approach taken in this study involves library and document analysis, with sources from the Sharicah, historical accounts from jurists and writers, and combined with empirical scientific evidence concerning the various coin (numismatic) and weights standards (metrology) adopted by Muslim dynasties. Whilst the dinar and the dirham fully satisfy the Islamic functions of money, as a unit of account or measure of value, we must acknowledge that certain types of medium of exchange are unlawful in Islam - for instance, using leather from swine. However, other types have also been excluded, such as promissory notes.

- "It was reported that Abu Hurairah (r.a.) asked Marwan: "Have you legalized usury?" Marwan said: "No." Then Abu Hurairah said: "You have legalized selling promissory notes (sukukun) whereas the Messenger of Allah (s.a.w.s.) forbade selling food-stuff unless received by the seller". Marwan then addressed the people and forbade selling such notes" (Muwatta, 1991, p.260).

Logically, sukukun include non-interest bearing non-redeemable promissory notes issued as paper currency by a central bank, such as the Federal Reserve's federal reserve note (the dollar) 
or Bank of England's (BoE) pound note. The latter still has the now broken "promise to pay the bearer the sum of five (10/20/50) pounds" of silver or gold, since the BoE paper notes were historically redeemable for bullion coins (BoE, 2020). The BoE tried to justify a new meaning of the word 'promise', where "public trust in the pound is now maintained by the operation of monetary policy, the objective of which is price stability", and yet central banks have broken this promise as well (Abdullah, 2013 Mar./Oct./Dec., 2015 Dec., 2016, 2018). Fiat money is largely debt organized into bank money (the medium of exchange is debt), where a customer promises to repay a debt, and the bank promises to repay a customer's deposit, thus bank credit involves exchanging two interest bearing IOUs, but such a "transaction would then come into the forbidden category of a debt for debt" (Muwatta, 1991, p.254).

Given Imam Ghazali's observation that "a counterfeit coin is one, which has got nothing of gold and silver. The coin in which there is something of gold and silver cannot be called counterfeit" (Ihya, 2004, 2, p.58), we must also logically conclude that modern alloy coins are also unlawful. Due to a shortage of an-nuqud, cUmar ibn al-Khattab (r.a.) contemplated using leather from camels as a medium of exchange (wasilat al-tabadul), but the sahabah advised against it since it would create a shortage of camels (Hail, 1999, p.145 cited by Haneef and Barakat, 2006, p.28) - hence despite the difficulties, Muslims knew that there would be ramifications for adopting something other than what the Sharicah had intended. Man is free to choose the medium of exchange, but there are repercussions if it is not an-nuqud and as mentioned, one of the Islamic functions of money involves an-nuqud within Sharicah legal requirements. Also, a specific hadith insists on the "prohibition of destroying dirhams and dinars";

- "cAlqama b. cAbdullah (r.a.) reported on the authority of his father that Allah's Messenger (s.a.w.s.) forbade from destroying the coins in vogue among the Muslims without any necessity" (Ibn Majah 12:2263, also Abu Dawud 23:3442).

We have therefore a specific injunction in the hadith that clearly states that Muslims cannot destroy the dirhams and dinars that were in circulation - if we cannot destroy them, surely we cannot discard them, only to adopt promissory notes and counterfeit coins, which have been specifically rejected by classical scholarship. Rasulullah (s.a.w.s.) "is said to have prayed for the continuation of [an-nuqud] for the ummah to exist as a prosperous community...[and] that gold and silver, whose currency values were measured in dinar and dirham, remained extremely stable over long periods of time in Islamic history" (Choudhury, 1997, p.92). Fiat money is backed by debt and owned by the central bank, and bank money (in the form of deposits) is not money at all, but merely represents non-cash credits and specifically involves a promise to pay fiat money upon demand; hence, demands deposits reflect a right, which will not be honoured if all the claimants exercises that right at the same time.

Unlike fiat money, one of the attributes of gold and silver is scarcity and the inability of alchemists to create bullion (money) out of nothing, may be contrasted with the modern alchemy of credit (money) creation from lending by the modern banking system (Abdullah, 
2018). An-nuqud has physically been used since the dawn of mankind, since the first person to mint the dinar and dirham was none other than Adam (a.s.) (Al-Maqrizi, 1994, pp.55-56). By the $7^{\text {th }}$ century, the Arabs primarily traded with the Romans and the Persians: "(It is a great Grace and Protection from Allah), for the taming of the Quraysh, (and with all those Allah's Grace and Protections for their taming, We cause) the (Quraysh) caravans to set forth safe in winter (to the south), and in summer (to the north without any fear)" (Al-Qur'an 106:1-2), and in so doing the Arabs brought back Byzantine gold from Ash-Sham in the form of Heraclian dinars, Sassanid silver in the form of Chosroes dirhams and also dirhams from Yemen. The Arabs referred to these gold and silver coins as an-nuqud (currencies), although naqd also means the payment of a price in dirhams, as relayed in the hadith of Jabir, "He paid (naqada) me its price" (Muslim 10:3886). Currency was clearly defined as: "nuqud is the plural of naqd and is composed of gold and silver" (Majallah, Art.130), and scholars wrote extensively on their usage, such as AlMaqrizi whom even wrote a book specifically entitled "The Islamic Currency" (al-Nuqud alIslamiyyah, 1967).

Muslims continued to use Heraclian dinars and Chosroes dirhams throughout the life of the Prophet (s.a.w.s.), and the Khalifah of Abu Bakr as-Siddiq (r.a.), up until the $8^{\text {th }}$ year of the Khalifah of "Umar (r.a.), when in $20 \mathrm{H}$ he coined dirhams in the Sassanid style retaining the Pahlavi faces but adding Kufic Arabic letters such "In the Name of Allah" or "In the Name of Allah, my Lord". However, in 75H the Umayyad caliph "Abd al-Malik ibn Marwan (r.a.), coined standardized dirhams in a specifically Islamic style, and in $77 \mathrm{H}$ he minted dinars at Damascus which also carried Islamic texts in the Kufic Arabic script, thus Muslims abandoned the currency of others and adopted their own, thus externalizing the theoretical coins and weights enjoined at the time of Rasulullah (s.a.w.s.). A number of Islamic injunctions rest upon the accurate knowledge of the weight and purity of the dinar and dirham, and the coins minted by ${ }^{\mathrm{c}} \mathrm{Abd}$ al-Malik ibn Marwan were exactly in conformity with the Sunnah in order to pay zakat (poor tax). Yet what was the weight and purity of the Islamic currency? Narrated Abdullah ibn cUmar: "The Prophet (s.a.w.s.) said: '(The standard) weight is the weight of the people of Makkah, and the (standard) measure is the measure of the people of Medina.'" (Abu Dawud 22:3334), since the Makkans were traders whilst the people of Medina were farmers. Yet, what is the Islamic legal coin standard and what are the relevant weights of Makkah? From the hadith, scholars, mint-masters and writers, and as noted by Ibn Khaldun (1958, 2, p.58) different regions had different weights and coin standards. We are confronted with a myriad of differing opinions as to what constitutes a legal mithqal and a dirham, whereas in fact, there is no conflict. Each mithqal, dirham, daniq, qirat, habbah and khardal are defined differently to describe the same weight standard stipulated by the Prophet (s.a.w.s.) later externalized by cAbd al-Malik ibn Marwan. Some narrations have clarified the specific relationships between the Byzantine dinar and the mithqal of Persia, Makkah, Syria, Egypt and Iraq. The key difference is in the actual weight of the qirats. The term 'Makkan mithqal', is used interchangeably and means the same as the 'Sharicah mithqal' or 'legal mithqal'. 


\section{Byzantine Dinar and Persian Mithqal}

Differing weight standards prevailed in Damascus (22 qirats less a habbah), Cairo (24 kharrubahs), Makkah (20 qirats), or Iraq (60 habbahs of 100 khardal) that would define a mithqal in a differing number of qirats, habbahs or qamhahs. The carat is the seed of the carob tree (ceratonia siliqua) and known as siliqua in Latin, keration in Greek and either qirat or kharrubah in Arabic. The siliqua was used as a weight, and as a coin. Theoretically, the Roman carat was the weight of the carob seed, and 24 carats equaled the dinar, and 72 dinars equaled a Roman pound (libra). Originally, the Roman dinar was the denarius aereus (Eagleton and Williams, 2007, p.88) and replaced by Constantine I in the year 312 with the Byzantine solidus, which also tariffed at $1 / 72$ of the Byzantine pound (litra). The late Roman and early Byzantine pound was theoretically $327.45 \mathrm{~g}$, and thus the solidus weighed $4.55 \mathrm{~g}$. The pound fell to $324 \mathrm{~g}$ by the $4^{\text {th }}-6^{\text {th }}$ centuries, to $322 \mathrm{~g}$ by the $6^{\text {th }}-7^{\text {th }}$ centuries, and then to $320 \mathrm{~g}$ in the $7^{\text {th }}$ century, given surviving pound and solidus weights in the British Museum (Entwistle, 2002, p.611) ${ }^{1}$. Thus, by the time of Heraclius the Byzantine pound weighed about $320 \mathrm{~g}$, and the contemporary Byzantine standard dinar of Heraclius was the full solidus of $4.4 \mathrm{~g}$ (Broome, 1985, p.11), or more precisely $4.44 \mathrm{~g}$ as reflected in surviving coinage, for example struck at Carthage in 629/630 (Grierson, 1999, p.6). However, the Byzantines also minted a reduced solidus at Carthage and other cities for trade with the East, which weighed a full solidus less a siliqua, or 4.25g (Broome, 1985, pp.12,14), and was the weight of a mithqal2. It is interesting to note that the Byzantine pound of 6,912 grains would later by adjusted into the Troy pound of 5,760 grains, by adjusting the scrupulum from 24 wheat grains to 20 barley grains, so that 288 scrupulum $\times 24=6,912$ wheat grains, and 288 scrupulum $\times 20$ barley grains =5,760 wheat grains: thus the Byzantine and also Persian metrological systems, were based on a wheat grain, so that the Byzantine full solidus and the Persian gold coins would weigh approximately $4.6 \mathrm{~g}$.

Indeed, the Persian systems would later influence the Il-Khanate (Persian, Iraq, Turkey) and Ottoman (Turkey/Anatolia) monetary systems, as reflected in the Tabriz mithqal, being distinct from the dinar mithqal, which weighed 72 grains of barley (Al-Maqrizi, 1994, p.57), since the former reflected a Persian coin standard of the Il Khanate and was based on the wheat grain rather than the barley grain (Kabaklarh, 2007, p.33). The mithqal was an ancient weight: in Persia it was historically derived from the weight of 24 chick-peas (nakhod), each weighing 4 gandums or wheat grains (Frey, 1917, p.151), whereas the Romans originally used karats (carob seeds), a term used by the Arabs (qirat). The Arabic word nuqud (gold and silver coins) is derived from the Persian nakhod (a weight for gold and silver). Mahmud Ghazan Khan (694704H/1295-1304), had no doubt learnt from the short reign and demise of his uncle Gaykhatu

\footnotetext{
${ }^{1}$ Each solidus would be weighed by a copper-alloy weight or exagium solidi: the English word 'assay' is derived from the Latin 'exagia', and 'soldier' is derived from 'solidus' (meaning 'solid' in Latin) reflecting the coin used as payment for his services. Fractions of the solidus known as semissis (half-solidi) and tremissis (one-third solidi) were also produced. Numismatics, or the study of currency, is derived from the ancient Greek word nomisma meaning 'money', and also means a 'coin' in Latin. The English word 'money' is derived from the Latin 'moneta', which means the 'mint' in which coins were struck ('as-Sikka' in Arabic).

${ }^{2}$ Mithqal referred to a weight and dinars were weighed with glass mithqal weights.
} 
Khan, following the latter's failed experiment at issuing paper money in 1294, and having moved the administrative capital of the Il Khanate to Tabriz in 1295, ordered in 696H/1296-7 that all coins of the regional governments, under the sovereignty of the Il-Khan, including the Ottomans, would be fixed according to the Tabriz mithqal, as part of his monetary reformation. Thus, the Ottomans paid taxes to the Il Khan in dirhams weighing $3.072 \mathrm{~g}$, and when they subsequently minted their first silver coin in 1326, the akche weighing $1.152 \mathrm{~g}$, it was supposed to be struck from a pure (halis ayar) silver (Pamuk, 2000, p.46), whilst in practice the Ottomans may have ty pically achieved a fineness of 23-231/2 carats (Kabaklarh, 2007, p.36). The akche was $1 / 4^{\text {th }}$ of the Tabriz mithqal or 6 karats $=6 \times 0.192=1.152 \mathrm{~g}$ and from 100 Tabriz mithqals 400 akche were minted $(100 \times 4.608$ / 1.152). Technically, the Ottoman monetary system involved monometallism, whereby one commodity standard existed, being the silver akche as the basic unit of account, in terms of which the value of other commodities are measured, even if the circulation of money may include several metallic or indeed paper units, including the gold sultani and the copper mangir.

During the Umayyads and cAbbasids the dinar was a recognized stable standard of payment, and was often used as a medium of exchange throughout the Mediterranean. By the time of the Mamluks, the $4.25 \mathrm{~g}$ dinar had been devalued by $20 \%$ in $829 \mathrm{H} / 1425$ to the $3.4 \mathrm{~g}$ ashrafi (named after Barsbay, al-Malik al-Ashraf), which was slightly lighter than the Venetian ducat and became the standard Mamluk gold coin. The first Ottoman gold coin, the sultani, was minted in $882 \mathrm{H} / 1477$ and was exchanged at par to the ducat, reflecting the latter's popularity as a trade coin. Ottoman coins were based on the Tabriz mithqal: from 100 Tabriz mithqals 129 sultanis were initially minted weighing 3.572g of 0.997 fine (Pamuk, 2000, p.63). The Tabriz mithqal $=24$ karats $=1.5$ dirhams. Each karat $=4$ habbah of wheat. Since the grain of wheat weighs approximately $0.048 \mathrm{~g}$, the karat $=0.192 \mathrm{~g}$, the Tabriz mithqal $=96$ habbahs $\times 0.048=4.608 \mathrm{~g}$, and the dirham $=4.608 / 1.5=3.072 \mathrm{~g}$ (Kabaklarh, 2007, p.33). In 1477, from 100 mithqals $=100 \times 4.608$ / $129=3.572 \mathrm{~g}$ Sultanis were minted. From 100 mithqals, the weight was reduced in 1526 to 130 sultanis (3.545g), and in 1564 to 131 sultanis (3.518g), with the 0.997 fineness unchanged (Pamuk, 2000, p.63). At that time, the Venetian ducat (zecchino or sequin) $=3.4909 \mathrm{~g}$ of 0.986 fineness or $0.1107 /$ troy oz actual gold weight (3.4909 x 0.986 / 31.103), comprising of 54 troy grains, was first minted in 1284, adopting similar standards to the florin of Florence which was struck in 1252.

Table 1 presents the Byzantine metrological system, and we may compare a Heraclian solidus of $4.44 \mathrm{~g}$ to the early Byzantine standard of $4.55 \mathrm{~g}$. The orientalists equate the sextula or mithqal as the full solidus, however when we deduct one siliqua from the $7^{\text {th }}$ century solidus we obtain the reduced solidus of $4.25 \mathrm{~g}$, being the equivalent weight of the actual mithqal, as reflected in the specific coins and glass weight identified in table 2 below. We may calculate the early Byzantine full solidus comprising 4 wheat grains of $0.0474 \mathrm{~g}$ per siliqua, with 24 siliqua per sextula, which equals $4.55 \mathrm{~g}(=4 \times 0.0474 \times 24)$; or we may say, 4 scrupulum of 24 grains each $0.0474 \mathrm{~g}$. The uncia (uqiyyah), or ounce, represents 6 sextula (= Byzantine dinar) or 8 drachma (= dirham al-kayl), or a ratio of $8: 6=11 / 3$, and when one applies the same Byzantine ratio to the 
Muslim mithqal coin standard of $4.25 \mathrm{~g}$ we obtain 3.186g (= 4.25 / 1.333), or a dirham weight based on the apothecaries' weight system. As reflected in table 4 below, the Islamic ratio between the legal dinar and dirham, whether between legal qirats (20:14), or legal habbas (72:50.4), is not $11 / 3$, but rather $13 / 7$, such that the legal dirham weighs $2.975 \mathrm{~g}$. Since 1958 , the modern Troy weight is now based on a nominal grain of $0.06479891 \mathrm{~g}$. Thus, 1 Troy oz of 480 troy grains $(=5,760 / 12)$ has a modern metric equivalent of $31.1034768 \mathrm{~g}$, the reciprocal of which is 0.0321507 Troy ozs / gram, and thus 1 metric tonne $=32,150.7$ ozs. 
Table 1: The Apothecaries Late Roman / Early Byzantine Metrological System

\begin{tabular}{|c|c|c|c|c|c|c|c|c|c|c|c|c|c|}
\hline Byzantine Name & $\begin{array}{l}\text { Arabic } \\
\text { Equivalent }\end{array}$ & & & & & & & & & & & $\begin{array}{l}\text { Byzantine } \\
\text { (gr.) }\end{array}$ & $\begin{array}{l}\text { 7th Cent. } \\
\text { (gr.) }\end{array}$ \\
\hline libra (pound) & ratl & 1 & & & & & & & & & & 327.45 & 319.50 \\
\hline uncia (ounce) & uqiyyah & 12 & 1 & & & & & & & & & 27.29 & 26.63 \\
\hline sicilicus (shekel) & double-dirham & 48 & 4 & 1 & & & & & & & & 6.82 & 6.66 \\
\hline sextula / solidus & dinar & 72 & 6 & 1.5 & 1 & & & & & & & 4.548 & 4.438 \\
\hline drachma & dirham al-kayl & 96 & 8 & 2 & 1.333 & 1 & & & & & & 3.411 & 3.328 \\
\hline $\begin{array}{l}\text { scrupulum } \\
\text { (scruple) }\end{array}$ & $1 / 4$ dinar & 288 & 24 & 6 & 4 & 3 & 1 & & & & & 1.1370 & 1.1094 \\
\hline obulus & daniq & 576 & 48 & 12 & 8 & 6 & 2 & 1 & & & & 0.5685 & 0.5547 \\
\hline siliqua (carob) & qirat & 1728 & 144 & 36 & 24 & 18 & 6 & 3 & 1 & & & 0.1895 & 0.1849 \\
\hline chalcus & & 4608 & 384 & 96 & 64 & 48 & 16 & 8 & 2.667 & 1 & & 0.0711 & 0.0693 \\
\hline grana (grain) & habbah & 6912 & 576 & 144 & 96 & 72 & 24 & 12 & 4 & 1.5 & 1 & 0.0474 & 0.0462 \\
\hline
\end{tabular}

Sources: EI (1993) “Dirham” pp.978-979, “Kirat” pp.1023-1024; Entwistle (2002), p.611; Broome (1985), p.11; Grierson (1999), p.6 
Table 2: Byzantine and Islamic Coins/Weights

\begin{tabular}{|c|c|c|c|}
\hline Dynasty & Ruler & Mint (Year) & Coin/Weight \\
\hline Heraclian & Heraclius & $\begin{array}{c}\text { Constantinople } \\
\qquad(610)\end{array}$ & $\begin{array}{l}\text { Full solidus } \\
\quad 4.44 \mathrm{~g}\end{array}$ \\
\hline Heraclian & Heraclius & $\begin{array}{c}\text { Constantinople } \\
\text { (613) }\end{array}$ & $\begin{array}{c}\text { Light-weight } \\
\text { solidus } \\
4.25 \mathrm{~g}\end{array}$ \\
\hline Umayyad & $\begin{array}{l}\text { cAbd al-Malik } \\
\text { ibn Marwan }\end{array}$ & $\begin{array}{c}\text { Damascus } \\
\text { (697) }\end{array}$ & $\begin{array}{l}\text { Mithqal dinar } \\
4.25 \mathrm{~g}\end{array}$ \\
\hline Abbasid & Harun al-Rashid & Egypt (808) & $\begin{array}{l}\text { Mithqal dinar } \\
\text { glass weight } \\
\text { (sanja) } 4.25 \mathrm{~g}\end{array}$ \\
\hline
\end{tabular}

Source: Amercian Numismatic Society (ANS, 2019)

\section{Makkan Mithqal}

In Rosenthal's translation of the Muqaddimah, Ibn Khaldun, the father of Islamic economics, observed: "It should be known since the beginning of Islam and the time of the Companions (sahabah) and the Followers (tabicun), the legal dirham is by general consensus the one, ten of which are equal to seven mithqal of gold, and an ounce of gold is forty dirhams. Thus, the legal dirham is seven-tenths of a dinar. A gold mithqal weighs seventy-two average-sized grains of barley (habbahs). Consequently, the dirham, which is seven-tenths of a mithqal, has a weight of fifty and two-fifths grains. All of these values are accepted by general consensus" (Ibn Khaldun, 1958, 2, p.58).

In Allouche's translation of the Ighathah, Al-Maqrizi, as a market prefect (mustahib), explained the weights of Makkah, that the daniq $=8.4$ habbah, that the daniq $=2.5$ qirats, the mithqal was 72 habbahs and the dirham 50.4 habbahs: "the mithqal, a weight for the dirhams and the dinars...[and]...the ratl, equivalent to 12 uqiyyahs, and the uqiyyah, equivalent to 40 dirhams. Thus, the ratl (of Makkah) would be equivalent to 480 dirhams... and one nish, which was onehalf of one uqiyyah, was equivalent to 20 dirhams, and one nawat was 5 dirhams." (Al-Maqrizi, 1994, p.56). Rasulullah (s.a.w.s.) established the nisab for silver as 5 uqiyyah, upon which a zakat

\footnotetext{
${ }^{3}$ In Rosenthal's 1958 English translation of the Muqaddimah, he translates habbahs as 'grains of wheat' when it literally means 'grain' but refers to an average-sized, unshelled grain of barley, of which the extremities are cut, whereas the qamhah is the wheat grain (c.f. Al-Maqrizi, 1994, p.57).
} 
of 5 dirhams (or one nawat) was fixed, and for every 20 dinars a zakat of $1 / 2$ dinar, thus the zakat rate is $2.5 \%$. Al-Maqrizi identified the weight of the daniq as " $82 / 5^{\text {th }}$ average unshelled habbahs [grains] of barley, of which the extremities are cut" (Al-Maqrizi, 1994, p.57), and "the daniq [was] two and a half qirats" (Al-Maqrizi, 1994, p.59). He noted that of the bahgli, tabaris, and jawrafi dirhams, the Persian baghli was also called the 'black of full weight' (sud wafiya) since it weighed the same as the dinar. Ten jawaz dirhams (a general term for the legal dirham) weighed 7 baghlis (or dinars or mithqals): "the weight of one mithqal... weighed 72 habbahs" of average unshelled grains of barley whose extremities are cut. (Al-Maqrizi, 1994, p.57), and "the weight of one dirham was fifty and two-fifths habbahs" (Al-Maqrizi, 1994, p.61).

In Fawzan Barrage's translation of Al-Dawhat al-Mushtabakat Fi Dawabit Dar al-Sikkah, AlHakim, an actual mint-master of Fas and a highly respected faqih, during the reign of the Marinid (Morocco) Sultan Abi 'Anan Faris (748-759H), corroborates the view of Ibn Khaldun and Al-Maqrizi, that the mithqal was 72 habbahs or 24 qirats $^{4}$, explaining that this is the same weight as the Sharicah mithqal: "the Romans (Byzantine) continued to use the dinar and the Persians to use the dirham, until Islam came...The Persians had three different weights for the dirhams: one was one mithqal, which is twenty qirats, another was twelve qirats and yet another was ten qirats. When Islam came, the need arose to value the zakat, so an average of all three standards was used. The sum of all three standards added up to forty-two qirats so it was agreed that the dirham would be equal to fourteen qirats of the qirats of the mithqal, which is in turn twenty-four qirats. The qirat was also equal to three habbahs and twenty-four times three is seventy-two and that makes a mithqal seventy-two habbahs... It is also said that when cUmar Ibn al-Khattab (r.a.), saw the discrepancy in the weight of the dirhams, he looked at the majority of what the people use from the lightest to the heaviest. He divided it into twelve daniqs and took half of that (six daniqs) to equal the dirham. Thus, when you add to the dirham three seventh of its weight it equals a mithqal, and when you take away three tenths off the weight of a mithqal, it equals a dirham" (Al-Hakim, 2001, p.2). In describing the history and inner working of the mint, Al-Hakim reported from Ibn Hazm al-Andalusi whom stated, "The Imam should order the people to transact between them with pure refined gold, and pure refined silver only ${ }^{5}$. The Imam is to recall all struck coins, smelt them and refine them. Then he is to strike new coins from the pure metal, and return these to their owners" (Al-Hakim, 2001, p.4).

In Wahba's translation of Al-Ahkam al-Sultaniyya, Al-Mawardi (974-1058), considered a judge par excellence (aqda al-quda), in Baghdad at the time of the cAbbasids, also corroborates the account of Al-Hakim as to how the legal dirham, as a coin standard, was maintained by cUmar (r.a.) amidst the declining state of Persian coinage:

\footnotetext{
4 There is also a tradition related on the authority of Jabir, states that the Prophet (s.a.w.s.) said: "The weight of the dinar is 24 qirats" (Zayas, 2003, p.72).

${ }^{5}$ As in the case of the early Heraclian and Chosroes coins, the Muslims did not transact by nominal value by 'tale' (i.e. by face value or by their official legal value) but by 'specie' (by their intrinsic weight as bullion) and considered them only as ore (tibr), i.e. pure material of gold and silver: the various weights were used to prevent fraud. In order to avoid injustice, when Islamic dinars and dirhams were transacted by their nominal value they should reflect their intrinsic worth since the population automatically trusted the sikkah (the mint).
} 
- "Now, the weight and quality of the dirham must be learned. Its weight has been fixed in Islam as six daniqs, and every ten dirhams weigh seven mithqals. There are different explanations for the reason why it was stabilized at that weight. It has been suggested, for instance, that dirhams were minted by the Persians in three weights: a mithqal or 20 carats, 12 carats and 10 carats. When a weight had to be considered for the purpose of paying the legal alms (zakat), the average weight, or the total of 42 carats divided by 3, was settled upon, and it equaled 14 carats. Islamic dirhams minted to match this average were then characterized as 10 per 7 mithqals, which is how it actually is. Others have argued that when cUmar ibn al-Khattab (r.a.) noticed the variety of dirhams in use, including the Baghlite, which weighed 8 daniqs, the 4 daniq Tabarite, the 3 daniq Maghribite, and the 1 daniq Yemenite, he ordered a study of the versions most used by all classes of people from the highest to the lowest. They turned out to be the Baghlite and the Tabarite. Adding them up and dividing the total of 12 by 2 , he arrived at 6 daniqs as the weight of the Islamic dirham. If you add to it $3 / 7^{\text {th }}$ of its weight you get a mithqal, and the latter minus $3 / 10^{\text {th }}$ yields a dirham; thus each 10 dirhams are equivalent to 7 mithqals, and each 10 mithqals are equal to 14 dirhams and $2 / 7^{\text {th }}$ of one dirham. The quality has to be pure silver, for no debasing admixture enters into its determination." (Al-Mawardi, 2000, p.170).

In Nyazee's translation of The Book of Revenue (Kitab al-Amwal), Abu 'Ubayd al-Qasim ibn Sallam (774-837), who was a judge and highly knowledgeable on jurisprudence, the Sunnah and history, at a time when the Hanafi school was established in Iraq, the Maliki school in Medinah and the Shafi'i school was just beginning to emerge in Syria and Egypt. Abu 'Ubayd had earlier provided a similar account on the Islamic currency to that of Al-Mawardi:

- "They used to make an assessment for the payment of zakat in two ways: separately from larger coins and from smaller coins. When they were about to commence minting of the dirhams, they examined the heavier dirham and found it to be 8 daniqs. Thereafter, they examined the samller dirham and found it to be 4 daniqs. They equalized the difference by combining the weight of the two and dividing into two equal dirhams, with each weight 6 daniqs. After this, they checked the weight of a dirham in terms of mithqals. The mithqal had remained of the same standard weight throughout. They took 10 of these dirhams, each with a weight of 6 daniqs and weighed them against mithqals. The weight came out to be exactly 7 mithqals...The sunnah about the dirhams was reaffirmed this way and the ummah arrived at a consensus, with no one disagreeing about the fact that the weight of the full dirham is 6 danigs. When a dirham was found to differ, it was called heavier or a deficient dirham...The weight of the dirham prior this was 6 [daniqs] and this has been mentioned in some traditions. It has been related to me from Sharik from Sa'd ibn Tarif from al-Asbargh ibn Nubata from Ali', who said: 'The Messenger of God (s.a.w.s.) married me to Fatima (r.a.), for a sum of 480 dirhams with a weight of six [daniqs]'." (Abu 'Ubayd, 2003, pp.480481). 


\section{Syrian Mithqal}

The Syrian mithqal was 22 qirats less a habbah, or 22 qirats less a fraction. Al-Maqrizi stated, "Abd al-Malik ibn Marwan "struck the dinar and the dirham: he set the weight of the dinar at 22 Syrian qirats minus one habbah, and that of the dirham at exactly 15 qirats, one qirat being equal to 4 habbahs, and one daniq at two and a half qirats...[he] struck gold (dinars) according to the Syrian mithqal. These were called the mayyalah dinars ('tilting' dinars), greater by two dinars per hundred" (Al-Maqrizi, 1994, pp.59-60). Since each Syrian qirat contained 4 habbahs, one Syrian mithqal thus equaled $87 / 88$ habbahs or a nominal $21.75^{6}$ qirats, which less $2 \%$ closely approximates the actual weight of $213 / 7^{\text {th }}$ derived from the dirham at 15 qirats being $7 / 10^{\text {th }}$ of the mithqal ${ }^{7}$. The Syrian mithqal of $213 / 7^{\text {th }}$ qirats equaled the Makkan mithqal of 72 habbahs (AlMaqrizi, 1994, p.57). Muhammad bin S'ad said, "The weight of these dirhams is 14 carats of the 20 carats of our mithqal which was 20 carats and it weighs 15 carats out of $213 / 7^{\text {th }}$ carats" (Zalloom, 2002, p.168). Indeed, the coins minted by 'Abd al-Malik ibn Marwan were readily accepted by the Muslims - Waqidi quoted that Wahb bin Kaysan said: "I saw dinars and dirhams, before cAbd al-Malik bin Marwan engraved and abraded them and they were the dinar's weight coined by 'Abd al-Malik" (Zalloom, 2002, p.167). It is also narrated from "Abd al-Malik bin As-Saib from Abu Wada'a as-Sahmi that he showed him the weight of the mithqal saying: "I weighed it and found it the weight of 'Abd al-Malik bin Marwan's mithqal. He Said: This was owned by Abu Wada'a bin Dhabira as-Sahmi in jahiliyyah." (Zalloom, 2002, p.167). Al-Balathri narrated from Uthman bin Abdullah who said: "My father said: 'The dinars of 'Abd al-Malik bin Marwan came to Madinah where there were some of the sahabah of Rasulullah (s.a.w.s) and others from the tabicin. No one rejected them'"' (Zalloom, 2002, p.168).

- Al-Baladhri narrated from Abdullah bin Th'alaba bin Sa'eer who said: "Heraclian dinars came to the people in of Makkah in jahiliyyah as came dirhams of al-Furs al-Bughliyya (Persians), and when they traded with them they considered them only as ore. The mithqal had a well-known weight for them, a weight of 22 carats less a fraction. Ten dirhams weighed seven mithqal and the pound was 12 ounces with each ounce being 40 dirhams. The Messenger of Allah (s.a.w.s.) consented to this, as did Abu Bakr, cUmar, cUthman and cAli." (Zalloom, 2002, p.165).

- According to Khalid b. Abi Rabi'ah from Ibn Hial from his father: "The pre-Islamic units of weight (mithqals) by which 'Abd al-Malik struck his coins were 22 qirats, minus a habbah; ten weight seven." (Al-Tabari, 1989, 22, p.91).

- According to 'Abd al-Rahman b. Jarir al-Laythi, from Hilal b. Usamah: "I asked Sa'id b. alMusayyab how much the zakat should be on dinars, and he said: 'For every 20 mithqals in Syrian weights, a half mithqal.' I said, 'Why Syrian rather than Egyptian?' He replied, 'It is the Syrian that dinars are struck, and that was the weight of the (earlier) dinars before the dinars were struck; they were 22 qirats minus a habbah' Sa'id said, 'I know that, because I

${ }^{6} 87$ habbahs $/ 4$ habbahs per qirat $=21.75$ qirats

${ }^{7}$ A dirham of 15 qirats $/ 0.7=21.428571$ or $213 / 7^{\text {th }}$ 
had sent some dinars to Damascus, and they were struck at that weight." (Al-Tabari, 1989, 22, pp.91-92).

\section{Eqyptian Mithqal}

We must differentiate between the legal and Egyptian mithqal, and also the coin standards of various dynasties. Although Bates states, "in Fatimid and Ayyubid Egypt, [the mithqal] was divided into 24 qirats and 72 habbahs" (Bates, 1981, p.78), in fact the mithqal weight varied depending on the type of grain. The legal mithqal was based on the barley grain (habbah), but the Egyptian kharrubahs was "equivalent to 3 qamhahs [wheat grains not barley grains] and the mithqal to 24 kharrubahs" (Al-Maqrizi, 1994, p.68). Al-Maqrizi clarifies that, "weight standards vary in Egypt and Syria: 100 Syrian mithqals weigh one and one-fourth mithqal less in Egypt, and this proportion is also true for the dirhams" (Al-Maqrizi, 1994, p.68). Ayyubid or Mamluk coin standards were based on an Egyptian mithqal that weighed 1.25\% heavier than the Syian (legal) weights, and weighed $4.303 \mathrm{~g}(=4.25 \times 1.0125)$ for the dinar and $3.012 \mathrm{~g}(=2.975 \times 1.0125)$ for the dirham, as reflected in surviving glass weights (Schultz, 2003, pp.67-69). Notwithstanding the prevailing coin standard, Egyptian bronze weights have been discovered and correspond to the legal mithqal weight 4.25g and dirham 2.975g (Bates, 1981, p.79).

Given the importance of our analysis on the accuracy of metrology and numismatics in determining the exact Egyptian weight and coin standards, we present the following figures relating to individual hoards of coins and glass weights for dinars, dirhams and fulus, from the Mamluk period, and the surviving specimens indeed reflect the Egyptian mithqal that weighed about $4.3 \mathrm{~g}$ and the dirham of about $3 \mathrm{~g}$. In figure 1, the combined average weight of 16 dinars is $4.303 \mathrm{~g}$ revealing the intention to conform to the Egyptian mithqal standard, being $1.25 \%$ more than the legal mithqal weight of 4.25g. The 11 Salimi dinars struck in 804-805/1401-1403 average $4.29 \mathrm{~g}$; and the implied average mithqal weight of the $5 \mathrm{Mu}$ 'ayyad full mithqal and half (nifs) mithqal dinars struck in $821 / 1418-1419$ is $4.33 \mathrm{~g}$. 
Figure 1: Distribution of Mamluk Dinars (16 coins)

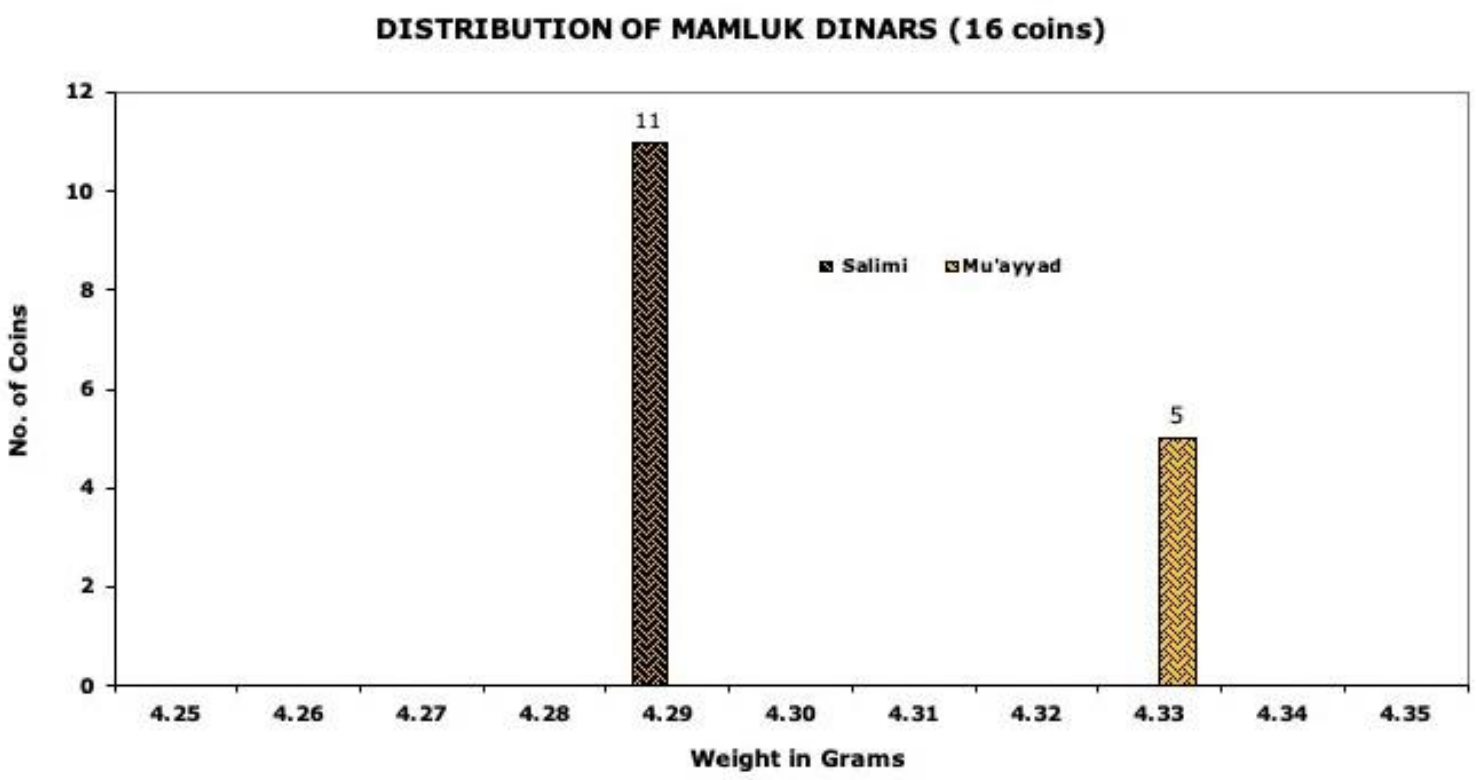

Source: Schultz (2003, pp.61-62)

In figure 2, out of 17 objects, 7 glass mithqal weights (41\%) with an average weight of $4.3 \mathrm{~g}$, are distributed within the range of 4.25 - 4.35g; and in figure 3, out of 10 objects, another 7 glass double-mithqal weights $(70 \%)$ with an average weight of $8.6 \mathrm{~g}$, are distributed within the range of 8.55 - 8.70g. In figure 4 , out of 77 objects, 65 glass half-dirham weights (84\%) with an average weight of $1.5 \mathrm{~g}$, are distributed within the range $1.45-1.55 \mathrm{~g}$; in figure 5, out of 291 objects, 245 glass dirham weights $(84 \%)$ with an average weight of $3 \mathrm{~g}$, are distributed within the range of 2.90 - 3.10g; and in figure 6, out of 379 objects, 323 glass double-dirham weights (85\%) with an average weight of $6 \mathrm{~g}$, are distributed within the range of $5.80-6.20 \mathrm{~g}$.

Figure 2: Distribution of Mamluk Mithqal Glass Weights (17 objects)

DISTRIBUTION OF MAMLUK MITHQAL GLASS WEIGHTS (17 objects)

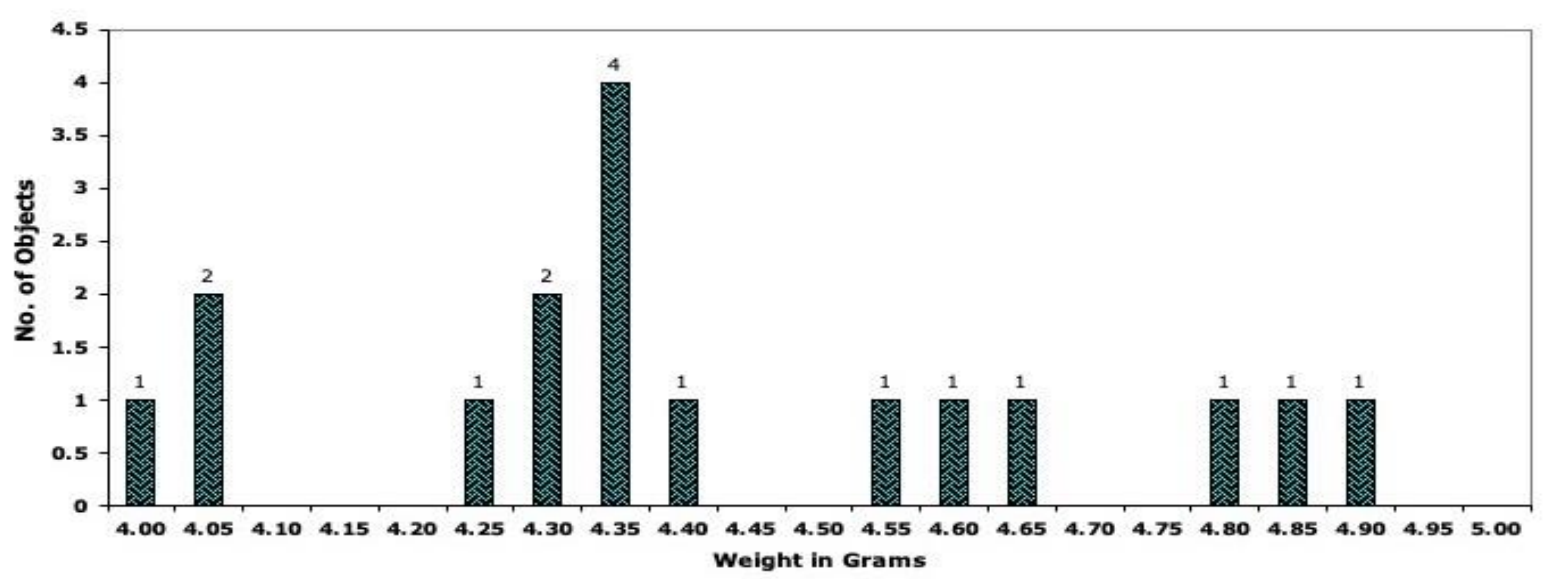

Source: Schultz (2003, p.70) 
Figure 3: Distribution of Mamluk Double-Mithqal Glass Weights (10 objects)

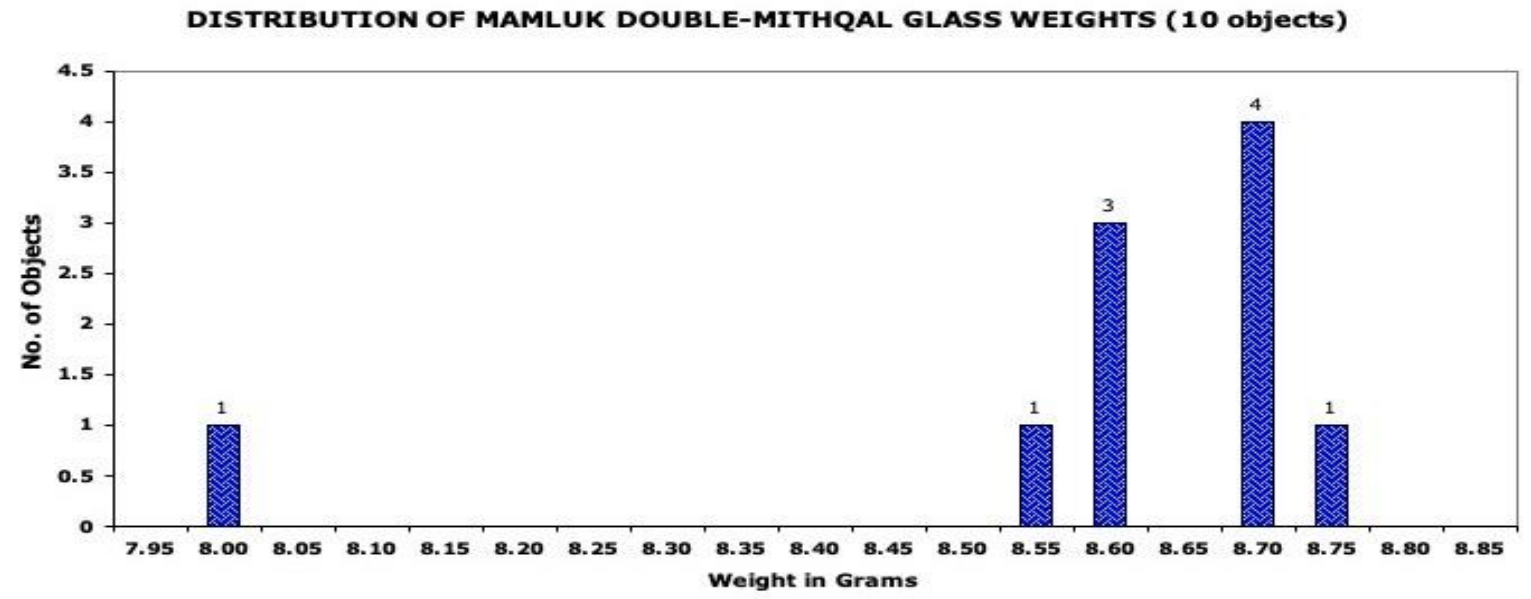

Source: Schultz (2003, p.71)

Figure 4: Distribution of Mamluk Half-Dirham Glass Weights (77 objects)

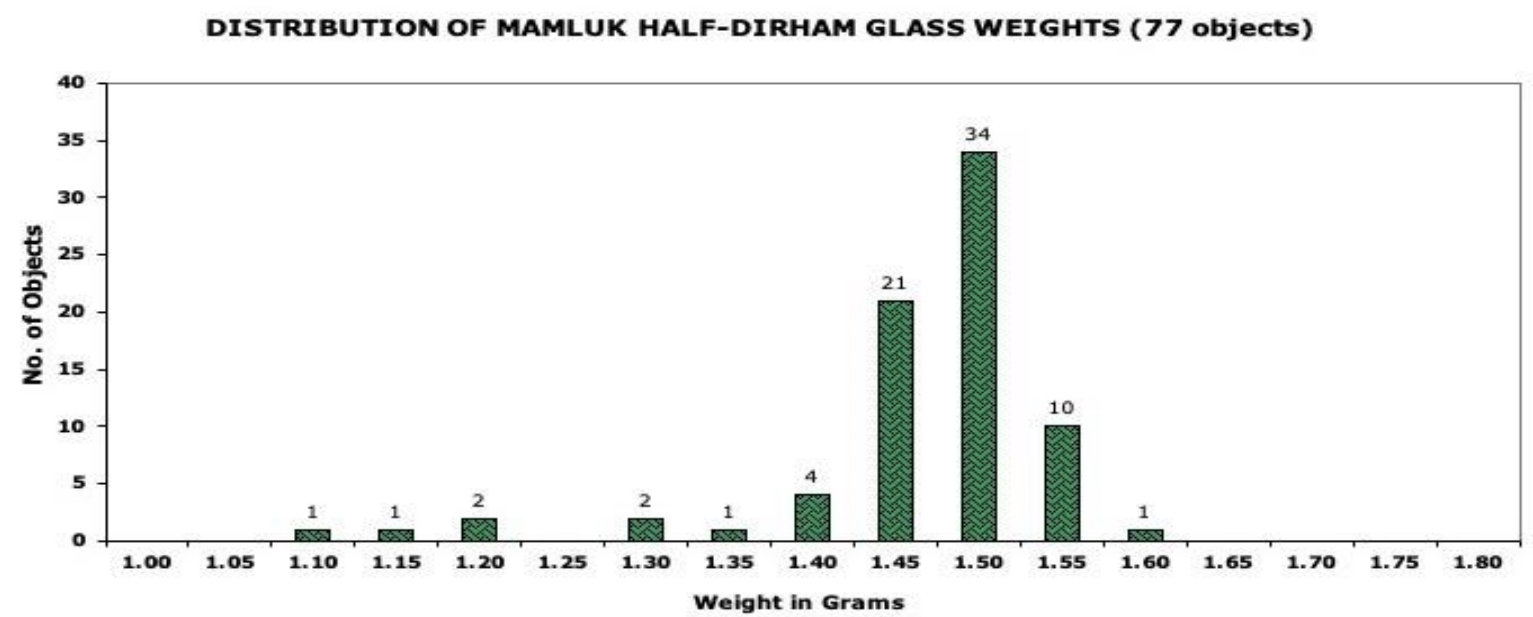

Source: Schultz (2003, p.67)

Figure 5: Distribution of Mamluk Dirham Glass Weights (291 objects)

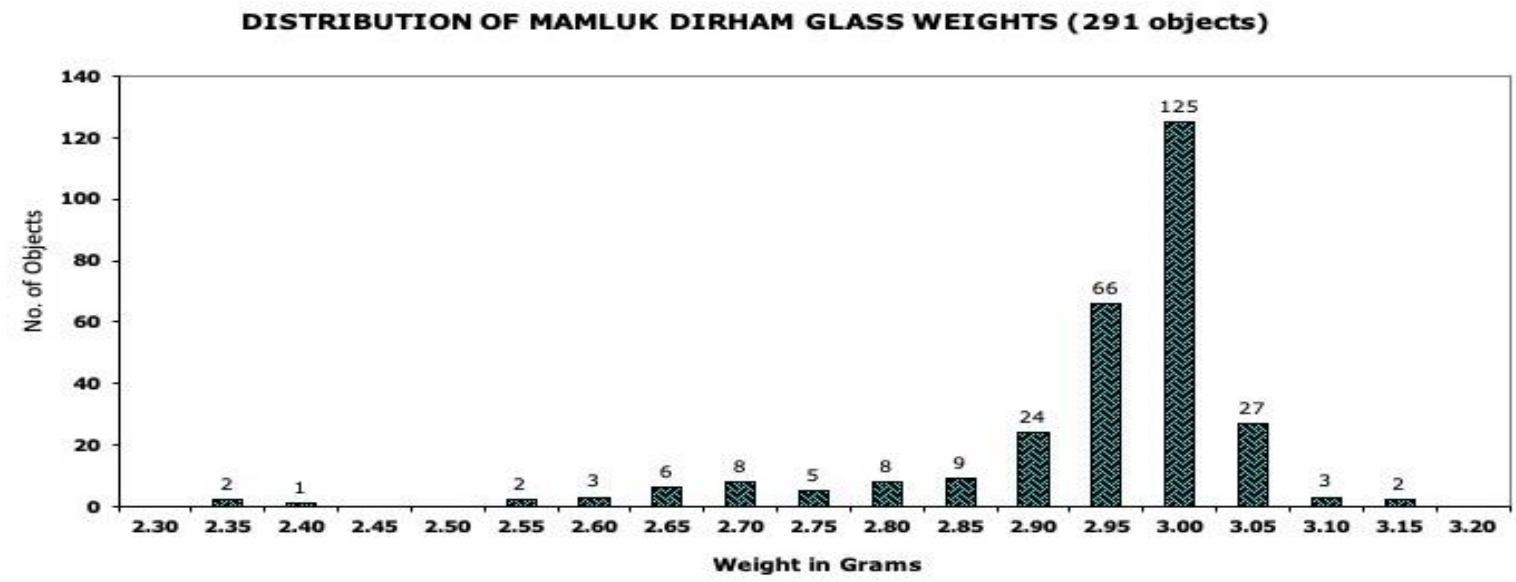

Source: Schultz (2003, p.68) 
Figure 6: Distribution of Mamluk Double-Dirham Glass Weights (379 objects)

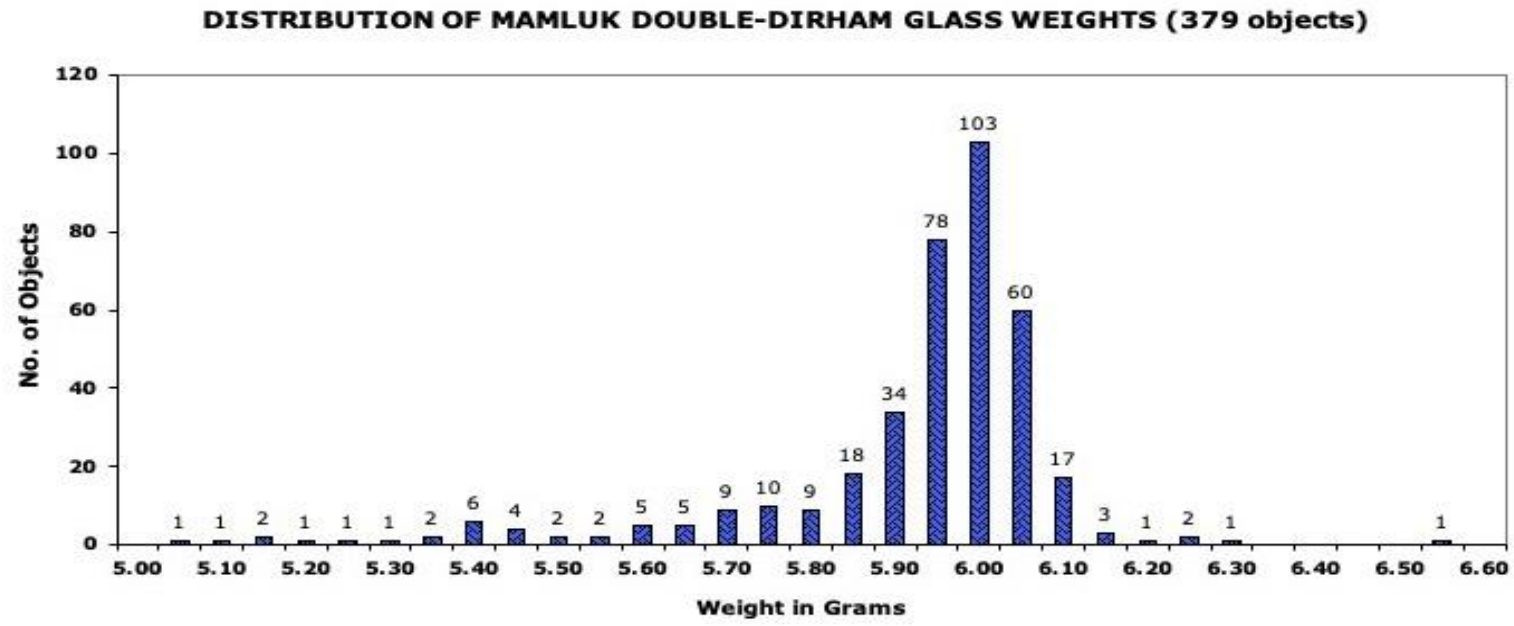

Source: Schultz (2003, p.69)

Figure 7: Distribution of Mamluk Fulus Coins (310 coins)

DISTRIBUTION OF MAMLUK FULUS COINS ( 310 coins)

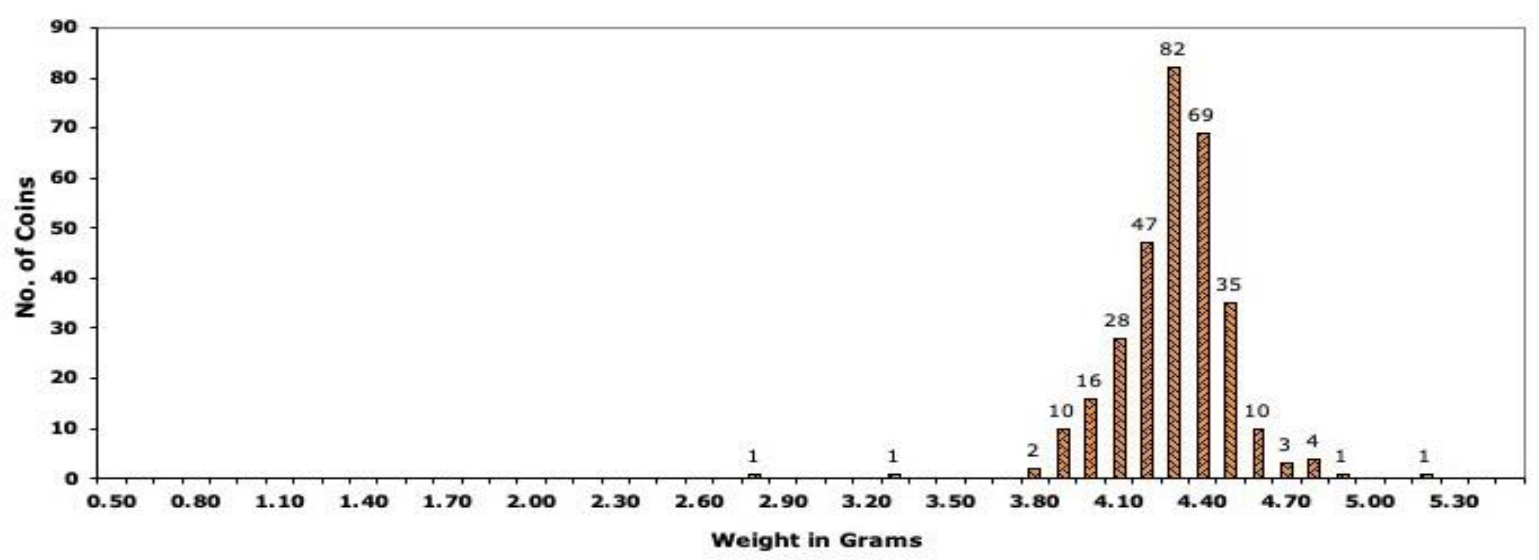

Source: Schultz (2003, p.63)

Finally, in figure 7, out of a hoard of 310 fulus that was minted in Cairo during the reign of alAshraf Nasir al-Din Sha'ban (764-778/1363-1376), 307 fulus copper coins (99\%) with an average weight of $4.302 \mathrm{~g}$, are distributed within a tight bell-curve between $3.80-4.10 \mathrm{~g}$, falling within an interval of 1.10g. Chronicles report that, after 759/1357-1358, 1 fals $=1$ Egyptian mithqal of $4.303 \mathrm{~g}$, and hence the intention was clearly to conform to Egyptian weights.

In 783H/1381-1382 seven copper coins were minted in Cairo, 6 of a full uqiyya weight and 1 of a half-uqiyya weight, with an implied average weight for the uqiyya of $34.86 \mathrm{~g}$. These coins have suffered some wear, however, in assessing for a reasonable adjustment for a loss in weights due to wear over time, Grierson suggested 1.5\% for gold and $0.5 \%$ for glass (Grierson, 1960, p.254). Since 1 uqiyya $=12$ dirhams, the dirham weight suggests $2.905 \mathrm{~g}$, and to obtain an Egyptian standard of $3.01 \mathrm{~g}$, one needs to adjust by $3.5 \%$ which is possibly too high for copper, and thus we probably require a larger number of specimens before arriving at any realistic conclusion 
(Schultz, 2003, p.64), as to whether these coins reflected the Egyptian equivalent of the Islamic ounce.

Al-Maqrizi also mentioned that the dirham kamali (DK) was fixed at 18 kharrubahs (Al-Maqrizi, 1994, p.68) or 54 qamhahs, so that by weight the Egyptian mithqal was 1.333 (24/18 kharrubahs or 72/54 qamhahs) heavier that the Egyptian dirham in circulation, which we know from AlMaqrizi's account, was the debased DK at 2/3 fine. Under the Ayyubids and Mamluks, the army dinar or dinar jayshi (DJ), a term derived from the diwan al-jaysh, was an important money of account used to determine the present value of agricultural land for land concessions (iqta') granted by the Sultan for military service, in lieu of a stipend. The DJ was payable in cash and in kind and worth the equivalent of $2 / 3$ of the Egyptian dinar (ED), being the same as the Egyptian mithqal (EM). On the basis of an exchange rate of $20 \mathrm{DKs}$ to $1 \mathrm{ED}$, the DJ was also equivalent by value to 13.333 DKs. Moreover, the dirham nuqra $(\mathrm{DN})^{8}$ was an official money of account that evaluated the pure metallic value of ordinary circulating dirhams, and exchanged at 13.333 DNs to 1 ED (Rabie, 1972, p.48; Goitein, 1965, p.43; Ehrenkreutz, 1992, IX, p.503).

From an analysis of coin specimens held by the American Numismatic Society (ANS, 2019), the Fatimid coin standard for the dinar was about 4.19g (Ehrenkreutz, 1959, p.180), a shortweight noticed in Collin's translation of Ahsan al-Taqasim fi Ma'rifat al-Aqalim, by AlMuqaddasi whom stated in 375H/985 that, "in all provinces of this region [the Maghrib], the standard is the dinar, which is lighter than the mithqal by a habbah, that is to say a grain of barley...The dirham is also short in legal weight...[coins] circulate by number [rather than by weight]" (Al-Muqaddasi, 2001, pp.198-199). A mithqal weighing 4.25g less a habbah, or 71/72 of the Sharicah mithqal, equals exactly $4.19 \mathrm{~g}$.

\section{Iraqi Mithqal}

Al-Maqrizi also states that the mithqal is a weight that has not changed since ancient times and was the equivalent of 60 habbahs, where each habbah weighed 100 grains of wild mustard (khardal), hence a mithqal weighed 6,000 khardal. The weight of the dirham was also 60 habbahs, but each habbah weighing 70 khardal, so that the weight of the dirham was 4,200 khardal, being $7 / 10^{\text {th }}$ of a mithqal (Al-Maqrizi, 1994, pp.57,62). In following the Iraqi practice of dividing the mithqal into 60 habbahs, "the $11^{\text {th }}$ century treatise of Eliya Bar-Sinaeus, Archbishop of Nisibin", Maqala fi'l-awzan wa'l-makayil, translated by Henri Sauvaire in 1877 and $1880 \ldots$ describes the

\footnotetext{
${ }^{8}$ With 1 DJ being equal to 2/3 of an ED (or EM), and a prevailing ED:DK exchange rate of 20:1, for a coin of the purity of a kamlili dirham (dirham al-nuqra al-kamiliyya), the DJ $=13.333(20 \times 0.666)$. Not all the dirhams in circulation were of $3 g$ and $2 / 3$ purity such as the DK, for some were of lower fineness and many were fractions. The DN was not the same as the DK as Borsch suggests (Borsch, 2005, pp.159-159 citing Schultz 1995, pp.147-149,163,234-224), but rather the DN was adopted as a monetary standard of account, to evaluate the metallic content of a coin, and used in other official capacities, for the evaluation of government salaries, in waqf documents and in legal documents as suggested by Goitein (1965, pp.35,37,43,46) and Ehrenkreutz (1992, IX, p.503). At 13.333 DN:1 ED, the DK weighed $3 \mathrm{~g}$ with $2 \mathrm{~g}$ of pure silver or .666 fine, and its pure silver (fidda al-nuqra) content would have a value of $13.333 / .666=20$. The gold:silver ratio for either the DK or the DN was therefore, $2 \mathrm{~g} \times 20 / 4.3 \mathrm{~g}$ for the DK, or, $3 \mathrm{~g}$ $\mathrm{x} 13.333 / 4.3$ for the $\mathrm{DN}=9.3$

${ }_{9}^{9}$ Nisibin is the modern Nusaybin in south-east Turkey, an ancient Assyrian city in upper Mesopotamia, close to the modern Turkish-Syrian border, within Kurdistan.
} 
procedure for making a set of weights for mithqals and dirhams, For mithqals, one begins with 100 mustard seeds, the weight of a gold-habbah, and makes from these a bronze weight for 1 habbah...using smaller weights in combination as the standard for larger weights, one makes a complete set...A set of dirhams weights is made the same way, beginning with a silver-habbah of 70 instead of 100 mustard seeds" (Bates, 1981, p.78).

Again, the weight of the habbah would not be the same weight of habbah expressed in the Egyptian, Syrian or Makkan mithqals, but nonetheless, the legal mithqal should weigh the equivalent of 6,000 khardal, and similarly the dirham weighs 4,200 khardal. The pre-Islamic Iraqi mithqal is distinct from Islamic cAbbasid dynasty (ruling from Baghdad), although some of their coins were light by one, two or even three habbahs, until the reign of Abu Ja'far al-Mansur (136-58H/754-75) whom minted hashimi dirhams according to the Basra mithqal, which was set according to the weight of Syrian mayyalah mithqal (Al-Maqrizi, 1994, p.63) at 21 and $3 / 7^{\text {th }}$ qirats. 
Tables 3 and 4 summarize historical coin and weight standards.

Table 3: The Mithqal in Relation to Historical and Modern Weights

\begin{tabular}{|c|c|}
\hline $\begin{array}{l}\text { Mithqal } \\
\text { Weight }\end{array}$ & Historical and Modern Weights \\
\hline Legal & $4.25 \mathrm{~g}$ of 20 qirats $=0.2125 \mathrm{~g}$ per qirat \\
\hline Mithqal & $\begin{array}{l}4.25 \mathrm{~g} \text { of } 8 \text { daniqs }=0.53125 \text { habbahs per daniq for gold } \\
4.25 \mathrm{~g} \text { of } 72 \text { habbahs }=0.0590277 \mathrm{~g} \text { per habbah } \\
4.25 \mathrm{~g} / 6000 \mathrm{khardal}=0.0007083 \mathrm{~g} \text { per } \mathrm{khardal} \\
6,000 \mathrm{khardal} / 72 \mathrm{habbahs}=83.33 \mathrm{khardal} \text { per habbah } \\
\text { dirham is } 7 / 10 \text { th of } 20 \text { qirats }=14 \text { qirats } \\
\text { dirham of } 2.975 \mathrm{~g} \text { of } 6 \text { daniqs }=0.495833 \mathrm{~g} \text { per daniq of silver }\end{array}$ \\
\hline Syrian & $4.25 \mathrm{~g}$ of 21.428571 qirats $=0.1983 \mathrm{~g}$ per qirats \\
\hline Mithqal & $\begin{array}{l}22 \text { qirats of } 4 \text { habbahs per qirats, less } 1 \text { habbah }=87 \text { habbahs } \\
\text { mayyalah dinars of } 21.75 \text { qirats ( } 87 \text { habbahs } / 4 \text { habbahs per qirat), less } 2 \% \\
\text { approx. }=213 / 7 \text { qirats } \\
\text { dirham }=15 \text { qirats being } 7 / 10^{\text {th }} \text { of the mithqal }\end{array}$ \\
\hline Egyptian & $4.303 \mathrm{~g}$ of 24 kharrubahs $=0.1793 \mathrm{~g}$ per kharrubah \\
\hline Mithqal & $\begin{array}{l}\text { Egyptian mithqal = } 72 \text { qamhahs or } 24 \text { kharrubahs }(3 \text { qamhahs per kharrubahs) } \\
\text { Al-Maqrizi: Egyptian mithqal > Syrian mithqal by } 1.25 \% \\
\text { Ayyubid, Mamluk coin standard }=4.303 \mathrm{~g}(4.25 \times 1.0125) \\
\text { Al-Muqaddasi: Maghribi dinar }=\text { legal mithqal less one habbah or } 71 / 72 \text { habbah } \\
\text { Fatimid dinar standard }=4.25 \mathrm{~g} / 72 \times 71=4.19 \mathrm{~g}\end{array}$ \\
\hline $\begin{array}{l}\text { Iraqi } \\
\text { Mithqal }\end{array}$ & $\begin{array}{l}4.25 \mathrm{~g} \text { of } 60 \text { habbahs }=0.0708333 \mathrm{~g} \text { per habbah } \\
\text { one gold habbah }=100 \text { mustard seeds }(\text { khardal }) \\
\text { one silver habbah }=70 \text { khardal } \\
\text { mithqal }=60 \text { habbah } \times 100 \text { khardal }=6,000 \text { khardal } \\
\text { dirham }=60 \text { habbah } \times 70 \text { khardal }=4,200 \text { khardal } \\
4.25 \mathrm{~g} \text { of } 6,000 \text { khardal }=0.0007083 \mathrm{~g}\end{array}$ \\
\hline $\begin{array}{l}\text { Byzantine } \\
\text { Solidus }\end{array}$ & $\begin{array}{l}\text { theoretically about } 4.55 \mathrm{~g} \text { of } 24 \text { siliqua }=0.1895833 \mathrm{~g} \text { per siliqua or carat } \\
\text { early Byzantine pound }=327.45 \mathrm{~g} \text {; by } 6^{\text {th }-7^{\text {th }}} \text { century fell to } 322 \mathrm{~g} \text {, then to } 320 \mathrm{~g} \\
\text { with devaluation of the pound, the siliqua no longer weighed a carob seed }\end{array}$ \\
\hline $\begin{array}{l}\text { Heraclian } \\
\text { Dinar }\end{array}$ & $\begin{array}{l}\text { the pound fell to about } 320 \mathrm{~g} \text { by } 7^{\text {th }} \text { century as per weights in British Museum } \\
\text { the reduced solidus was a full solidus less a siliqua, tariffed at } 1 / 72 \text { of a pound } \\
\text { the reduced solidus = the mithqal, and used for trade with the Orient } \\
\text { hence the reduced solidus of } 24 \text { siliqua }=0.1770833 \mathrm{~g} \text { per siliqua or carat }\end{array}$ \\
\hline
\end{tabular}


Table 4: The Dinar and Dirham, and Regional Coin and Weight Standards

\section{Heraclius (Byzantine) dinar}

\begin{tabular}{|c|c|c|c|c|c|c|c|c|c|c|}
\hline $\begin{array}{c}\text { An-Nuqud } \\
\text { \& the Sassanian } \\
\text { drachma of } \\
\text { Khosrau II }\end{array}$ & $\begin{array}{l}\text { Weight } \\
\text { in } \\
\text { Mithqals }\end{array}$ & $\begin{array}{l}\text { Legal } \\
\text { Qirat }\end{array}$ & $\begin{array}{l}\text { Legal } \\
\text { Daniq }\end{array}$ & $\begin{array}{l}\text { Syrian } \\
\text { Qirat } \\
2^{1 / 2} \text { qirats } \\
\text { to } 1 \text { daniq }\end{array}$ & $\begin{array}{c}\text { Weight in } \\
\text { Habbahs } \\
\text { barley } \\
\text { grains }\end{array}$ & $\begin{array}{c}\text { Egyptian } \\
\text { Qirat } \\
3 \text { habbhas } \\
\text { to } 1 \text { qirat }\end{array}$ & $\begin{array}{c}\text { Iraqi Mithqal } \\
=60 \text { habbahs }(\mathrm{h}) \\
1 \text { gold } \mathrm{h}=100 \mathrm{k} \\
1 \text { silver } \mathrm{h}=70 \mathrm{k} \\
\text { khardal (k) wild } \\
\text { mustard seeds }\end{array}$ & $\begin{array}{l}\text { Weight } \\
\text { in } \\
\text { grams }\end{array}$ & $\begin{array}{c}1 \text { pound }=72 \\
\text { full solidus } \\
\text { of } 24 \text { siliqua } \\
\text { (carobs) } \\
\text { in grams }\end{array}$ & $\begin{array}{c}\text { mithqal = } \\
\text { reduced } \\
\text { solidus } \\
\text { of } 23 \text { siliqua } \\
\text { (carobs) } \\
\text { in grams }\end{array}$ \\
\hline legal dinar & 1 & 20 & & $213 / 7$ & 72 & 24 & 6000 & 4.25 & 4.44 & 4.25 \\
\hline $\begin{array}{c}\text { Baghli } \\
\text { (the mule) }\end{array}$ & 1 & 20 & 8 & & & & & & & \\
\hline $\begin{array}{c}\text { Juwariqiyya } \\
\text { Dirham } \\
\text { (from Jurqan) }\end{array}$ & $3 / 5$ & 12 & & & & & & & & \\
\hline $\begin{array}{c}\text { Tabri } \\
\text { (from } \\
\text { Tabaristan) }\end{array}$ & $1 / 2$ & 10 & 4 & & & & & & & \\
\hline legal dirham & $7 / 10$ & 14 & 6 & 15 & $502 / 5$ & $164 / 5$ & 4200 & 2.975 & & \\
\hline
\end{tabular}


Table 5 specifically highlights the differences between the 'full' and 'reduced' solidus. Orientalists often argue that Muslims merely copied the Byzantine dinar, but the mithqal preceded the Romans. The Muslims never used actual carob seeds to weigh gold and silver, but barley grains, and ultimately it was the Byzantines that reduced their solidus to trade with the Persians and the Arabs.

Table 5: Full and Reduced Solidus of Heraclius

\begin{tabular}{|c|c|c|c|c|c|c|}
\hline $\begin{array}{l}\text { Heraclian } \\
\text { Dinars }\end{array}$ & $\begin{array}{l}\text { Pound } \\
\text { (grams) }\end{array}$ & $\begin{array}{l}\text { Solidus } \\
\text { pound }\end{array}$ & per & $\begin{array}{l}\text { Solidus } \\
\text { (grams) }\end{array}$ & $\begin{array}{l}\text { Siliqua per } \\
\text { Solidus }\end{array}$ & $\begin{array}{l}\text { Siliqua } \\
\text { (grams) }\end{array}$ \\
\hline Full Solidus & 320 & 72 & & 4.44 & 24 & 0.185 \\
\hline $\begin{array}{l}\text { Reduced } \\
\text { Solidus }\end{array}$ & 306 & 72 & & 4.25 & 23 & 0.185 \\
\hline
\end{tabular}

Sources: Broome (1985), pp.11,12,14; Grierson (1999), p.6; Entwistle (2002), p.611

Another interesting aspect of metrology is the underlying synergy of the dinar, dirham, mithqal and daniq in every ancient currency. The Persian daniq was not only a weight but also a small coin, exactly similar to the Greco-Roman obol: 6 daniqs or 6 obols being equal to 1 Sassanian drahm or Attic drachma. Also, the shekel meaning 'weight' has its roots in Mesopotamia, the Akkadian 'she' meaning 'barley', with the half shekel being the weight of the mithqal. Since Britain and France (Gaul) were former Roman provinces, the British pound has the Roman abbreviation for $L$ (libra) with a stroke through it, and $£ 1=240$ pennies; also 'shilling' came from the word solidus, and the pennyweight (pwt or dwt), with abbreviation ' $d$ ' from the silver denarius. English coinage was derived from the French Carolingian reform, which spread under King Charlemagne to the Saxon kingdom of Mercia under King Offa (757-796), and thus, $£ 1=20$ s, each containing $12 d$ (and the half penny equaled the obol). Each penny initially weighed 30 wheat grains under the Tower pound, up until 1527 when the Troy system was adopted and each penny weighed 24 barley grains.

\section{Makkan Weights}

We may summarize the Makkan weights with their modern metric counterparts as follows;

1 legal mithqal $/$ dinar $=20$ qirats $=8$ daniqs $=72$ habbahs $=6,000$ khardal $=4.25 \mathrm{~g}$

1 legal dirham $=14$ qirats $=6$ daniqs $=50.4$ habbahs $=4,200$ khardal $=2.975 \mathrm{~g}$

hence 7 mithqals $=10$ dirhams, so $7 \times 4.25=29.75 \mathrm{~g}$

and 10 dirhams $=7$ mithqals, so $10 \times 2.975=29.75 \mathrm{~g}$

1 legal qirat $=4.25 / 20$ or $2.975 / 14=0.2125 \mathrm{~g}$

1 legal gold daniq $=4.25 / 8=0.053125 \mathrm{~g}$ 
1 legal silver daniq $=2.975 / 6=0.4958333 \mathrm{~g}$

1 legal habbah $=4.25 / 72$ or $2.975 / 50.4=0.059028 \mathrm{~g}$

1 uqiyyah of 40 legal dirhams $=40 \times 2.975=119 \mathrm{~g}$

1 nish $=1 / 2$ of 1 uqiyyah $=20$ dirhams $=20 \times 2.975=59.5 \mathrm{~g}$

1 ratl of 12 uqiyyahs $=12 \times 40=480$ dirhams $=480 \times 2.975=1,428 \mathrm{~g}$

5 uqiyyahs $=$ nisab for silver $=200$ dirhams $=200 \times 2.975=595 \mathrm{~g}$

1 nawat $=$ zakat on silver ${ }^{10}=5$ dirhams $=5 \times 2.975=14.875 \mathrm{~g}$

Legal exchange rate for zakat $=10$ dirhams to 1 dinar, and the nisab for gold $=20$ dinars $=85 \mathrm{~g}$,

thus, the zakat on gold $^{11}=1 / 2$ dinar $=2.125 \mathrm{~g}$

\section{Dirham Weight}

With respect to the dirham weight, an analysis is warranted as to its accurate weight, for some writers, perhaps influenced by orientalists, have sought to differentiate between the legal silver dirham and a dirham weight. The silver dirham is referred to as the dirham al-kayl, or the dirham of measurement, since the legal ratl, sac and mudd are multiples of it (Al-Maqrizi, 1994, pp.61,87.90), where $1 \mathrm{mudd}=1 / 4 \mathrm{sa}^{c}=11 / 3^{\text {rd }}$ (Baghdadi) ratls. Nonetheless, some have given varying estimates for the dirham weight: Zalloom (2000, p.54) stipulates $3.17 \mathrm{~g}$ (thereby arriving at $408 \mathrm{~g}$ for the Baghdadi ratl, and the same figure as Al-Qardawi, 2005, p.239). Allouche (1994, p.89) suggests $3.186 \mathrm{~g}$, based on Popper $(1957,16: 39)$ whom cites $3.186 \mathrm{~g}$ and $3.148 \mathrm{~g}$ from Zambaur (EI, 1993, pp.978-979,1023-1024), with an average of 3.17g; the French Commission cites 3.0884g in 1799 and 3.0898g in 1845 (Sauvaire, 1884, 4, p.317); and Popper (1957,16, p.39) cites 3.12g in Egypt or 3.2g in Palestine and Syria from Baedeker. Whilst the ratl (of 12 uqiyyahs) in Makkah was 480 silver dirhams (of 2.975g), in Cairo the ratl (pound) was 144 dirhams of the time (Al-Maqrizi, 1994, p.56). Atiya stated 1 ratl of 144 dirhams weighed 499g in modern Egypt, with each dirham weighing (1/144 of 449) 3.12g (Popper, 1957,16, p.39; EI, 1993, p.1129).

Notwithstanding, various weights assessed by the orientalists, the important determinant for the weight of the legal dirham was the legal mithqal, since post-reform by Umar ibn Al-Khattab (634-644) the legal dirham weighed $7 / 10^{\text {th }}$ of the mithqal. The legal mithqal or dinar weighed 72 habbahs or $4.25 \mathrm{~g}$ and the legal dirham weighed 50.4 habbahs or $2.975 \mathrm{~g}$. As mentioned, the mithqal weight was also evident in earlier civilizations, such as the silver coinage of Ancient Greece and Persia. In particular, table 6 presents the mithqal drachma of Alexander the Great (336-323 BC) and similarly of the Sassanian rulers Yazdegerd II (438-457) and Khusrau II (590-628). At the time of the Prophet (s.a.w.s.), the dirhams reflected the weight standard of the Sassanian drahm of Khusrau II that circulated in Makkah and Madinah. As cited by Al-Mawardi and Abu

\footnotetext{
10 "No zakat is due on property mounting to less than five uqiyyahs (ounces of silver)" (Bukhari 24:487) and "for silver the zakat is one-fortieth" (Bukhari 24:534)

${ }^{11}$ From al-Hassan ibn "Umar through cAli that the Prophet (s.a.w.s.) said, "bring forth the zakat on gold [at the rate of] one-half dinar for every twenty dinars" (Ibn Rushd, 2003, 1, p.297)
} 
Ubayd, during the Rashidun Caliphate, the dirhams were reformed by Umar ibn Al-Khattab (634-644), although the earliest surviving dated Arab-Sassanian dirham was minted from the coinage of Yazdigird III (632-651) by Uthman bin Affan (644-656), engraved with Bismillah (in the name of Allah), in the year 651/31AH (Broome, 1985, p.5).

Table 6: Greek, Persian, Arab-Sassanian and Islamic Dirham Coins

\begin{tabular}{|c|c|c|c|}
\hline Dynasty & Ruler & Mint (Year) & Coin \\
\hline Macedon & $\begin{array}{c}\text { Alexander III } \\
\text { (Alexander the } \\
\text { Great) }\end{array}$ & $\begin{array}{l}\text { Colophon } \\
(320 \text { BC) }\end{array}$ & $\begin{array}{c}\text { drachma } \\
4.23 \mathrm{~g}\end{array}$ \\
\hline Sassanian & Yazdigird II & $\begin{array}{l}\text { Ardashir } \\
\qquad(450)\end{array}$ & $\begin{array}{l}\text { drahm } \\
4.25 \mathrm{~g}\end{array}$ \\
\hline Sassanian & Khusrau II & $\begin{array}{c}\text { Jayy (Isfahan) } \\
(627)\end{array}$ & $\begin{array}{l}\text { drahm } \\
4.24 \mathrm{~g}\end{array}$ \\
\hline $\begin{array}{l}\text { Rashidun } \\
\text { Caliphate }\end{array}$ & $\begin{array}{l}\text { Uthman bin } \\
\text { Affan } \\
\text { (Yezdigird III) }\end{array}$ & $\begin{array}{l}\text { Sijistan } \\
\qquad(651)\end{array}$ & $\begin{array}{l}\text { drahm } \\
3.0 \mathrm{~g}\end{array}$ \\
\hline Umayyad & $\begin{array}{l}\text { cAbd al-Malik } \\
\text { ibn Marwan }\end{array}$ & $\begin{array}{c}\text { Damascus } \\
\text { (699) }\end{array}$ & $\begin{array}{l}\text { dirham } \\
2.975 \mathrm{~g}\end{array}$ \\
\hline
\end{tabular}

Source: Amercian Numismatic Society (ANS, 2019)

\section{Conclusion}

In this study, we have clarified the nature of the Islamic monetary standard. Ibn Khaldun (1958) and Al-Maqrizi (1994) both warned Muslims against abandoning the Islamic currency. Ultimately, the ${ }^{\mathrm{C}}$ Abbasids lost their caliphate to the Ottomans in 1517 as a result of currency mis-management and manipulation through debasement and devaluation with fiat (copper) money (Abdullah, 2016). The Ottomans similarly lost their Caliphate to paper money and external debt (Abdullah, 2013, Mar.). Given a continuous cycle of financial crises in modern times, we should equally reflect on the consequences of avoiding a currency with intrinsic value. At a personal level, our wealth and assets are being eroded. We calculate the nisab (of $85 \mathrm{~g}$ of gold) according to the equivalent price of gold in fiat (paper) money, in order to determine whether our assets in nominal terms are zakatable. If we first calculated zakatable wealth in real terms in terms of gold, then since 1971 the gold price has risen from USD 35/oz 
to about USD 1,250/oz, and we would soon realize that in real terms, the value of our wealth and the value of the zakat in terms of fiat currency have both essentially collapsed. The positive effect of zakat in lifting the poor out of poverty has been entirely lost due to exponential decay in the value of money (reflected in its higher rate of exchange with a fixed amount of gold), as a result of an excessive increase in the supply money (generated by the modern banking system and the combined deposit and lending rates of interest), in relation to the demand for money, the effect of which is an increase in prices. This Islamic monetary theory of value (Abdullah, 2016), takes into account value, supply and demand, such that the cause is the decline in the value of money and the effect is price inflation. Since interest rates and prices are positively correlated, we are forced to lower our standard of living to pay for higher prices, such that our wealth is being confiscated through inflation and transferred to the combined profit-and-loss statement of the banking system. The fiat standard is money backed by debt, and is being exponentially devalued by aggregate interest rates (riba). Absent of usury, our medium of exchange would increase in value and purchasing power, thus lowering prices. Interest is a circular argument: it does not protect the value of money - it devalues it. When we pause to reflect, how can a nation hope to increase its wealth, increase its means of paying others, by charging interest upon itself. Our current monetary system involves debt at interest organized into currency and is not sustainable. Accordingly, we should to appreciate the importance of the Islamic monetary standard, and recognize that it was the once and is also the future of money, as the Prophet (s.a.w.s) has foretold, "A time is certainly coming over mankind in which there will be nothing (left) which will be of use save a dinar and a dirham" (Imam Ahmad ibn Hanbal, Musnad). 


\section{References}

Abdullah, A. (2013, Mar.). "Examining the Value of Money in England Over the Long Term (1259-2009)". International Journal for Economics and Finance. Vol.5, No.3, pp.73-89.

Abdullah, A. (2013, Oct.). “Examining the Value of Money in America Over the Long Term (1792-2009)". International Journal for Economics and Finance. Vol.5, No.10, pp.58-84.

Abdullah, A. (2013, Dec.), "Examining the Value of Money in Turkey Over the Long Term (1469-2009)", Asian Social Science, Vol.9 No.17, pp.187-208.

Abdullah, A. (2015, Dec.), “Economic Security Requires Monetary and Price Stability: Analysis of Malaysian Macroeconomic and Credit Data", Al-Shajarah, Special Issue on Islamic Banking \& Finance, pp.205-247.

Abdullah, A. (2016, Apr.), “An Islamic Monetary Theory of Value and Equation of Exchange: Evidence from Egypt (696-1517)”, Humanomics, Vol.32, Issue 2, pp.212-150.

Abdullah, A. (2016). The Islamic Currency. Kuala Lumpur: ICIFE.

Abdullah, A. (2018). Money and the Real Economy: An Islamic Perspective, Kuala Lumpur: IIUM Institute of Islamic Banking \& Finance (II $i \mathrm{BF})$.

Abu ‘Ubayd al-Qasim ibn Sallam. (2003), The Book of Revenue (Kitab al-Amwal), trans. by Imran A. K. Nyazee, Reading: Garnet.

Al-Ghazali, Abu Hamid Muhammad ibn Muhammad. (2004), 'Ihya' Ulum-Id-Din, trans. by AlHaj Maulana Fazlul Karim, 4 Vols., New Delhi: Islamic Book Service.

Al-Hakim, Abi al-Hasan `Ali b. Yusuf. (2001), Al-Dawhatal-Mushtabakat Fi Dawabit Dar al-Sikka, trans. by Fawzan Barrage, Chapter 5, As- Sikka Islamic Coins Group.

Al-Maqrizi, Ahmad ibn Ali. (1994). Mamluk Economics, a Study and Translation of Al-Maqrizi's Ighathah (Kitab Ighathat al-Ummah bi-Kashf al-Ghummah) (Book of Aiding the Ummah by Investigating the Depression), first published in Egypt in 1405, trans. by Adel Allouche, Salt Lake City: University of Utah Press

Al-Maqrizi, Ahmad ibn Ali. (1940), Kitab Ighathat al-Ummah bi-Kashf al-Ghummah, Muhammad Mustafa Ziyadah and Jamal al-Din Muhammad al-Shayyal (Eds.), Cairo: Lajnat al-ta'lif wa'l-tarjamah wa'l nashr (2/e, 1957).

Al-Maqrizi, Ahmad ibn Ali. (1967), al-Nuqud al-Islamiyah; al-musamma bi-shudhur al-uqud fi dhikr al-nuqud, Muhammad al-Sayyid Ali Bahr al-Ulum (Ed.), Najaf: al-Maktabah alhaydariyah.

Al-Mawardi, Abu al-Hassan. (2000), The Ordinances of Government, Al- Ahkam al-Sultaniyya, originally written 1045-1058, trans. by Wafaa H. Wahba, Reading: Garnet.

Al-Muqaddasi, Shams al-Din Abu Abd Allah Muhammad bin Ahmad bin Abi Bakr al-Banna al-Shami. (2001), The Best Divisions for Knowledge of the Regions, Ahsan al-Taqasim fi Ma'rifat 
al-Aqalim, first published 735H/985, trans. by Basil Collins, reviewed by Mohammad Hamid Alta'i, Reading: Garnet.

Al-Qardawi, Y. (2005). Figh Az-Zakat. London: Dar Al Taqwa.

Al-Tabari, Abu Ja'far Muhammad bin Jarir. (1989), The History of al-Tabari, Vol.XXII The Marwanid Restoration, The Caliphate of 'Abd al-Malik, trans. by Everett K. Rowson from Ta'rikh al-Rasul wa'l Muluk (The History of Prophets and Kings), New York: State University of New York Press.

[Allouche], see Al-Maqrizi, Ahmad ibn Ali, Mamluk Economics, a Study and Translation of AlMaqrizi's Ighathah.

[ANS] American Numismatic Society (2019), retrieved from http://numismatics.org/

Ashtor, E. (1969), Histoire des prix et des salaires dans l'Orient médiéval, Paris: S.E.V.P.E.N.

Bank of England [BoE], (2020), "General Banknote Questions", retrieved from https://www.bankofengland.co.uk/faq/banknote

Bates, M. L. (1981, Jan.) “The Function of Fatimid and Ayyubid Glass Weights”, Journal of the Economic and Social History of the Orient, Vol.24 No.1, pp.63-92

Borsch, S. J. (2005), The Black Death in Egypt and England, Austin, Tx: University of Texas Press

Broome, M. (1985). A Handbook of Islamic Coins, London: Seaby.

Choudhury, M. A. (1997). Money in Islam: A Study in Islamic Political Economy. London: Routledge.

Eagleton, C. and Williams, J. (2007). Money, A History. Buffalo: Firefly.

Ehrenkreutz, A. S. (1959, May), "Studies in the Monetary History of the Near East in the Middle Ages: The Standard of Fineness of Some Types of Dinars", Journal of the Economic and Social History of the Orient, Vol.2 No.2, pp.128-161

Ehrenkreutz, A. S. (1992), Monetary Change and Economic History in the Medieval Muslim World, Aldershot: Variorum.

[EI], Houtsma, M. T. et al., (Eds.), (1993), The Encyclopaedia of Islam: A Dictionary of the Geography, Ethnography and Biography of the Muhammadan Peoples, 8 Vols. and 1 Suppl., first published between 1913-36 and reprinted, Leiden: E.J. Brill.

Entwistle, C. (2002), "Byzantine Weights", in The Economic History of Byzantium: From the Seventh through the Fifteenth Century, Angeliki E. Laiou (Ed.), Washington D.C.: Dumbarton Oaks Research Library and Collection, pp.611-614

Frey, A. R. (1973). A Dictionary of Numismatic Terms, published (1917) New York: American Numismatic Society, published (1947) New York, Barnes \& Noble, and London, Spink \& Son. 
Goitein, S. D. (1965, Aug.), “The Exchange Rate of Gold and Silver Money in Fatimid and Ayyubid Times: A Preliminary Study of the Relevant Geniza Material", Journal of the Economic and Social History of the Orient, Vol. 8 No.1, pp.1-46

Goitein, S. D. (2000), A Mediterranean Society, The Jewish Communities of the Arab World as Portrayed in the Documents of the Cairo Geniza, Volume 1: Economic Conditions, 6 Vols., Berkeley and Los Angeles: University of California Press

Grierson, P. (1960, Oct.), “The Monetary Reforms of 'Abd al-Malik: Their Metrological Basis and Their Financial Repercussions", Journal of the Economic and Social History of the Orient, Vol.3 No.3, pp.241-264

Grierson, P. (1999), Byzantine Coinage, (1/e 1982), 2/e, Washington D.C.: Dumbarton Oaks

Hail ‘Abd al-Hafid (1999), “Taghayyur al-Qimah as-Shira'iyyah Li an-Nuqud al-Wariqiyyah, Dirasat Fi al-Iqtisad al-Islami (Raqm 35)", Herndon, VA.: International Institute of Islamic Thought (al-Mahad al-'Alami Li al-Fikr al-Islami).

Haneef, M. A. and Barakat, E. R. (2006), “Must Money Be Limited to Only Gold and Silver?: A Survey of Fighi Opinions and Some Implications", JKAU: Islamic Economics, Vol.19, No.1, pp.21-34

Ibn Khaldun. (1958), Muqaddimah, first published in 1377, trans. By Frank Rosenthal, 3 Vols. New York: Pantheon.

Ibn Rushd, Abu al-Walid Muhammad ibn Ahmad. (2003), The Distinguished Jurists Primer, Bidayat al-Mujtahid wa Nihayat al-Muqtasid, first published 584H/1184, trans. by Imran Ahsan Khan Nyazee, reviewed Mohammad Abdul Rauf, Reading: Garnet.

[Ighathah], see Al-Maqrizi, Ahmad ibn Ali, Mamluk Economics, a Study and Translation of AlMaqrizi's Ighathah.

[Ihya], see Al-Ghazali, Abu Hamid Muhammad ibn Muhammad, 'Ihya' Ulum al-Din.

Imam Malik ibn Anas ibn Malik ibn 'Amr al-Asbahi. (1991), Al-Muwatta' of Imam Malik ibn Anas, trans. by Aisha Abdurrahman Bewley, Inverness: Madinah Press.

Kabaklarh, N. (2007). Ottoman Copper Coins Minted in Tira 1411-1516. Istanbul: Tire Belediyesi. Majallah. (2001), The Mejelle: Being An English Translation of Majallah el-Ahkam-I-Adliya, And A Complete Code of Islamic Civil Law, enacted in Imperial Turkey between 1869 and 1876, trans. by Tyser C. R., Demetriades D. G. and Effendi, I. H. in 1901. Petaling Jaya: The Other Press.

Meloy, J. (2003), The Merits of Economic History: Re-Reading al-Maqrizi's Ighathah and Shudhur, Mamluk Studies Review, Vol.7, No.2, pp.183-203

[Muwatta], see Imam Mālik ibn Anas ibn Malik ibn 'Āmr al-Asbahi, Al-Muwatta' of Imam Malik ibn Anas. 
[Nuqud], see Al-Maqrizi, Ahmad ibn Ali, al-Nuqud al-Islamiyah.

Pamuk, S. (2000). A Monetary History of the Ottoman Empire. Cambridge: Cambridge University Press.

Popper, W. (1955-1957). Egypt and Syria under the Circassian Sultans 1382-1468: Systemic Notes to Ibn Taghri Birdi's Chronicles of Egypt, University of California Publications in Semitic Philology, Vols.15- 16, Berkeley and Los Angeles: University of California Press

Rabie, H. M. (1972), The Financial System of Egypt, A.H.564-741/1169-1341, London: Oxford University Press.

Sauvaire, M. H. (1879-1887). Matériaux pour servir à l'histoire de la numismatique et de la métrologie musulmanes, Paris: Journal Asiatique, $7^{\text {th }}$ series, 14 (1879:455-533); 15 (1880:228-277,421478); 18 (1881:499-516); 19 (1882:23-77,97-163,281-327), Deuxième partie - Poids, $8^{\text {th }}$ series, 3 (1884:386-345); 4 (1884:207-321); 5 (1885:498-506), Troisième partie - Mesures de capacité, $8^{\text {th }}$ series, 7 (1886:124-177,394-468); 8 (1886:113-165,272-297), Complément, $8^{\text {th }}$ series, 10 (1887:200-259)

Schultz, W. (1995), Mamluk Money from Baybars to Barquq: A Study Based on the Literary Evidence and the Numismatic Evidence, $\mathrm{PhD}$ dissertation, University of Chicago

Schultz, W. (2003, Mar.), "Mamluk Metrology and the Numismatic Evidence", published by Routledge in Al-Masaq, Islam and the Medieval Mediterranean, Vol.15 No.1, pp.59-75

Schultz, W. (2008), “The Monetary History of Egypt, 642-1517”, in The Cambridge History of Egypt, Volume 1: Islamic Egypt, 640-1517, Vol.1 640-1517 Carl F. Perry (Ed.), Vol.2 15172000 M. W. Daly (Ed.), Cambridge: Cambridge University Press, originally published 1998, reprinted 2008, pp.318-338

Shoshan, B. (1983, Feb.), "Money Supply and Grain Prices in Fifteenth Century Egypt", published by Blackwell on behalf of the Economic History Society, The Economic History Review, New Series Vol.36 No.1, pp.47-67

Udovitch, A., Lopez, R. and Miskimin, H. (1978), “England to Egypt, 1350-1500: Long Term Trends and Long-Distance Trade", in Studies of the Economic History of the Middle East, from the Rise of Islam to the Present Day, M. A. Cook (Ed.), first published (1970), reprinted London: Oxford University Press, pp.93-128

Usmani, M. T. (2001), The Text of the Historic Judgment on Riba given by the Supreme Court of Pakistan 23 ${ }^{\text {rd }}$ Dec. 1999, Petaling Jaya: The Other Press.

Zayas, F. G. de (2003), The Law and Institution of Zakat, first published (1960), Petaling Jaya: The Other Press.

Zalloom, A. Q. (2002), Funds in the Khilafah State, New Delhi: Milli Publications. 